\title{
Democratic Deficit and Political Economy of Critical Citizenry: Nigeria in Perspective
}

\author{
Ogbonna, Emmanuel Chijioke \\ Department of Political Science and Public Administration, Adeleke University, Nigeria
}

\begin{abstract}
This research work is situated \at the evidence that a vast percentage of Nigerians resent political participation, abandoning the political process entirely to the political elites, their social and business backers. The situation sees the continual erosion of the social contract and to be apt democratic deficit. To this extent, leadership descends to self-service, policy clueless, corrupt, and developmentally deficient; in fact a social burden. Nonetheless, the bye product of the critical exercise of citizenship is nothing but good governance; therefore it is of moment to infuse a new paradigm into Nigerian political perception - equating both followership and leadership on equal pedestal on Nigerian polity; deficit which equals 'de-development'. However, toeing the line of political democracy and its classicalist implications, the continuous renewal of the social contract is just but necessary by all citizenry and in all strata of the society, through active participation. 'Democratic intermediators' - civil society, political parties, and religious organisations as well as academic institutions should fine-tune themselves playing the significant role of mobilization towards political transformation vis-a-vis development.
\end{abstract}

Keywords: Critical citizenry, Development, Democracy, Democratic Deficit, Good governance

\section{Introduction}

Long established, democracy is better than all the other tried systems of government, in fact it is a state's political best practice. Democracy is not given on a platter of gold, it is struggled for by those hitherto subjected to oppressive government, who when they get it, remain on guard against reversal. Eternal vigilance is therefore the price of democratization, by the general citizenry. Democracy usually, is an unfinished process, anytime, everywhere (Beetham 1994[1]). The justification for the democratic system lies on its imperative for good governance. If governance implies a complex mechanisms, process, relationships and institutions through which citizens and groups articulate their interests, exercise their legal rights, meet their obligations and mediate their differences (UNDP 1999[2]) it is democracy that sets some basic principles according to which a good government, whatever its form, must be run (Oluwole, 2003[3]). In fact, more often than not 'good governance' is the buzz word for 'democratic governance', granting that if the essence of "governance is for citizens to seize the initiative and reclaim their rightful place as the catalysts of social change" (Imade 2012[4]) then it is only democratic governance that provides this opportunity. To this end, democracy as a political system shares contiguity with economic development on one hand, and on the other what makes democracy democratic is the extent of its accommodation of the wide array of state's citizens' capacity in determining the configuration of government, becoming part of it, and shaping the process and condition the outcome as well. Liberal democracy is predicated on free market system characterized by laissez-faire economic policies which encourages competitive investment of varying proportions, allowing the market forces to shape the tide of the economy. Axiomatic though, political democracy implies popular participation by the citizens to make choice and these choices in turn impact every breath of the state's existence.

Nigeria has recorded a long breadth of democratization, however, the development imperative of democracy is not only thin but the polity suffers from the potentialities of reversal. A prognosis in this direction shows a troubled polity sickened by apathy and followership mortgage of their 'power' of choice. Leadership soars without direction, at best policy clueless or confuse. Significantly, the debris of party politics remain monumental with implications that shakes the very foundation of the Nigeria state typified in security challenges and the reign of terror in the Northern part of the country, perfunctory or lip-service effort by the political mayors of the region to arrest the quagmire, the grasping of leadership deficit in this regard to drive home expensive sentiments by opposition parties. In all, the Nigerian state is not only trapped in compound complexity but portrays an image of 'audacity of hopelessness'.

\section{Democracy: A Theoretical Construct}

This research work is situated within the principles of Political democracy. Key in this school of thought is the Schumpeterian perspective of political democracy which implies that "the democratic method is that institutional arrangement for arriving at political decisions in which individuals acquire the power to decide by means of a competitive struggle for the peoples' vote." (Schumpeter 1947:269[5]). Stretched out by Dahl 
(1989:221[6]), a democracy is a "polyarchy" characterized by the following seven elements: (1) elected officials; (2) free and fair elections: (3) inclusive suffrage; (4) the right to run for office; (5) freedom of expression; (6) alternative information; and (7) associational autonomy. Political Democracy orchestrates Karl Popper's (1945[7]) 'principles of open society', implying "a society which is democratic and pluralistic, within which incompatible views are expressed and conflicting aims pursued; a society in which everyone is free to investigate situations and to propose solutions; a society in which everyone is free to criticize the proposed solutions of others, most importantly those of the government, whether in prospect or application; and above all, a society in which the Government's policies are changed in the light of reasonable and constructive criticism; a society where the rulers can be changed by the ruled without resorting to violence".

The proponent of political democracy believes that there is a democracy/development nexus vis-à-vis good governance; given that 'political democracy' is predicated on 'supremacy' of the choices of the masses. It allows for the decisions of the greater number of the population to be absolved into government policy option and action; which combined with the liberal-economic corollary of a democratic polity on the long run has developmental implications. The democracy/development nexus is an exploration of the economic canons of democracy. The logic is that political participation elicits responsiveness which on the long run accounts for the materialization of the good of the greater number of the masses either in terms of safety and rule of law, participation and human rights, sustainable economic opportunity, etc. all leading to human development.

\section{The Nigerian Democratic Experience: Problems Arising}

The British colonial rulers handed over power to Nigeria civilian indigenous politicians in 1960. In less than a breadth of 6 years Nigeria lost the democratic system to military adventurists who waded into power fronting a reformist agenda and alleging political abuse by the civilian government. From 1966 till 1999 the military conveniently ventured in and out of Nigerian politics, for a period totaling nearly four decades. In 1999, Nigeria excitedly returned to the democratic track (Aina 2004:83[8]) and has remained on course, haven recorded 13 years of uninterrupted democratic experience, four 'electoral terms' (the 1999, 2003, 2007 and 2011 general elections) for both the legislature and the executive at both the national and state levels; with a lot of policies and politics schemed to depoliticized the military.

The above a decade of democratization effort in Nigeria is yet to manifest capacity towards advancement (to liberal and advanced democracy) and 'persistence'. The political-economy imperative of the democratic system manifested in quality of life, human security, infrastructure, etc, in all 'public good' being the reason and purpose of governance is eclipsed by the general problems of holistic systemic and structural deficits, military debris, criminalization of party politics, and political culture of poverty; symptomized by electoral fraud, gross human rights violations, incessant insurgencies and general insecurity, perpetual political instability, economic crises, corruption, wasteful spending by government, diseases and poverty (Albert 2011[9]).

Despite that Nigeria is two years away from being hundred years of existence as a single nation-state, it has not departed from the expression of being an " an alien will" (Soyinka 2000: 5[10]). The British sole purpose of putting Nigeria together was solely commercial (Ayoade 2010:4[11]). Strategic to British colonial interest Nigeria was amalgamated without integration (Ayoade 2010[12]), and this was manifested in a preponderance of master scheme to create a dominant pole (favourable to colonial interest) in the Nigerian politics, evidence in the rigging of both the first census and the first general elections in Nigeria to favour the North. This development ironically makes the entire political poles (geopolitical zone/region) of the state losers, better still creating dominate poles in politics without concomitant development, setting the tune for an enduring skewed politicking and manipulation for self-service and class interest that is yet to vacate the Nigerian democratic space.

The holistic structural lopsidedness that was foisted on Nigeria soon paved a fertile pathway for political rancor that soon graduated into incessant military interruption of the political order. The military involvement in politics left its own deep-seated debris. The military in power not only stagnated development, they also suppressed the political culture fertile to house democratic values and popular participation. Worst still, a growing culture of militancy was established typified in the 'use and show of force' in social relations manifested in areas ranging from collecting market dues, shop and house rents, local government levies and dues, sanitation levies and penalties, contesting for political positions and other offices, and even assertion of the authority of office of varying proportions become predicated on the harnessing of the instrument of force brandished either through the abusive harnessing of the state's element of coercion or the contracting and or employment of thugs and any other element of violence that could compel obedience to a collectivity.

The 'military officers' on retirement waded into active politics with a proportional grip of the economy as evident in their holdings in both private and public companies (Adekanye 1999[13]). The military factor (economic control, active partisan politics and long term psychological implication of long term military rule over the general public) instilled a deep-seated culture of political resentment by the citizens. As observed by Cyril (2007[14]); 
The militarisation of politics is the antithesis of democracy, which thrives by seeking to close the political space, disempower and depoliticise the citizens so they can no longer freely participate in decision making, or contest for access to power and resources.... Militarisation of politics cannot be separated from the disempowerment of democracy.

Sooner than later, the citizens jettisoned their social contract to self-serving leadership who are dedeveloping the country by political and economic mismanagement (Okunade 2008: 3[15]). While the research concurs with Okunade (2008: 15[16]) that leadership is important in development and problem solving, however, will not be in a haste to agree that "leadership than anything else is the proposed solution to all accomplishments" (Okunade 2008[17]). The reason is that followership has remain a cardinal aspect of democratic leadership and from the $18^{\text {th }}$ century sinking of the 'ancient regime' in France to the most recent 'Arab spring' and holding of popular elections in Egypt and Libya, 'people-power' has remained the dynamics of good governance. Worthy of re-emphasis is that democracy is an unending contract between followership and leadership. In fact, leadership failure is not subject to self correction as rights will only be gifts when the citizens wait for leadership to enter a political monologue which is a political aberration. Political participation is a human right permissible by law, gives government direction, checks the exercise of power by leadership and allows the citizens to call the shorts on how they are to be governed. In fact if the citizens wish to be the sole determinant of government formation and primary repository of government policies, they should form the government, interrogate and check the government, confront the government and send the government packing at 'good-governance-standard-deviations'.

The civil and political society (made up of autonomous self organising groups and party politics) on their own only reflect the popular attributes of the people that makes them up. While the civil society led by the Nigerian Labour Congress (NLC) and Trade Union Congress (TUC) is constantly loosing fuel and alternating gears. In recent times the NLC and TUC find itselves on short term agitations on wage related issues; the veracity with which it fought military governance to standstill from 1993 to 1999 has remained missing in action. More often than not the civil society in Nigeria is saturated with the same element constituting the opposition political parties and operates within this boundary.

Party politics has been criminalized; Aina (2002:7[18]) aptly observed that the integrity of political participation and competition in Nigeria is in doubt. Political parties in Nigeria portends a vehicle of political utility and convenience, bereaved of ideology, and deficit in both ideas and principle, characterized by immoderate migrations for greener political pasture. Political parties that brands themselves 'opposition' are merely opposing in name, seeking only a regional grip on power, or mere replacement of the ruling political party without deepening the ingredients of alternative information, civic education, quality policy debate and checkmate vital to democratization; instead, the so called opposition parties are entrapped in a web of destructive primordial sentiments which further deepens the precarious political and security situation in the country. Evidence till date has proved that the ruling and opposition parties are only concerned with gaining and consolidating power without making a conscious target to offer good governance.

As a fall out from dangerous power politics, Nigeria is fast becoming ungovernable with increasing security challenges threatening the very foundation of its unity. The government at best "is a disguised dictatorship delivering governmentalism rather than governance". With the people suffering a reversal of rising expectations as the potentials of the country is sabotaged by pretentious governance and self-serving elite (Ayoade 2010: 50[19], The Economist, February 27 - March 5, 2010[20]). The citizens must rise to these challenges, given that "peoples determination of leaders, public policy, and participation in governance" (Nwolise 2006: 3[21]); in essence consensus makes the democratic system to survive the endless irritations and frustrations of elections and party competition (Dahl 1956[22]). Noting could be farther from the fact that "politics is not a spectator game. It is participative and inclusive game" (Ayoade 1997:2[23]), and as such protest participation manifested through apathy can only produce catastrophic result in a dwindling leadership environment.

\section{Good Governance: Concept And Theory}

Conceptualizing good governance is better done from the stand point of state specificity. Good governance is difficult to conceptualize and or generalize, though a variety of indices and indicators has always been reeled out for the measurement of good governance. Governance on its own implies the institutional and structural arrangements, decision making processes, policy formulation and implementation capacity, development of personnel, information flows and the nature and style of leadership within a political system (Ogundiya 2010:203[24]) in essence identifying 'public good' and making provisions towards such. The Board of the Mo Ibrahim Foundation (2011[25]) opined that governance is inclusive from the view point of the citizens, accounting for what a citizen has the right to demand from his/her government, as inherent in four over-arching dimensions: safety and rule of law, participation and human rights, sustainable economic opportunity and human development. Be this as it may, the conceptualization of good governance is better done 
with the understanding of "public good". The following challenges have remained consistent and pervasive in Nigeria despite resources reeled out by different governments in providing solutions;

- High poverty rate compared to Nigerian human and natural resources

- Human security deficit including food and yet to be surmounted eco challenges, like erosion, oil spillages, flooding, etc

- Infrastructural deficits including deficient health services, as well as under dosage electricity

- Collapsing of the manufacturing sector

- High rate of unemployment and poverty

- Human capital depreciation syndrome, and brain-drain syndrome

- Crippling and non-problem solving educational sector

- Epileptic bureaucracy, crippled by corruption and ethnocentric vices

The whole notion of good governance is central to the understanding that every state is endowed with both human and natural resources. Invariably, every state is of two cardinal constituents - the citizens and the government; the government is contracted through election in a democratic setting to carry out the functions of authoritative allocation of resources. The successful fulfillment of the mandate of allocating resources to solve the problems of the masses as well as the strategic vision to not only harness but generate resources for the state remains nothing but good governance.

\section{Democratic Governance And Development}

The justification for the democratic system is that it is the only political system that enables the citizens to engage in obligatory contract with their leaders. The citizens defines and sets the tune of governance; making the choice of who governs, when and how, "a society where the rulers can be changed by the ruled without resorting to violence" (Popper [7], Mbachu 1991[26]). To this end the democratic system is usurped as good governance. Outside the power of the citizens in choosing their leaders and determining how they are to be governed, setting political agenda and offering their support to policies that will lead to mass prosperity or dissent policies perceived as anti-masses; the development imperative of democracy ranges from naturally accompanying free market system that allows private investors and engenders competition that enables the economic strengthening of the state and development measured by such clear social indices like, "availability of good water, access to good health care, existence of human security, number of children in school, etc" (Nwolise 2006: 6[27]). Invariably, citizens determinant of leadership configuration, style and policy remain a popular choice with implications on structural changes in all ramification of the state, such that lead to increase in modes of production, technological advancement, restructuring of education to suit local challenges, as well as free flow of international transactions through foreign direct investments and other international relations usually anchored on good and democratic governance, which may include aids, military support, technological transfer, obtaining loans from international organisations like the IMF, Paris Club and World Bank, attracting international sympathy in times of natural disaster and economic challenges. In a whole having the good-will and reputation that endears a state to the 'big democracies'.

\section{When Is Democracy In Deficit?}

First of all, when is democracy balanced? Ordinarily every credible system of government is measured by its ability to bequeath good governance which is mainly providing the basic needs of the general citizenry. Democracy is the only system of government that allows the masses to contract government, and creating a balance depends on the responsiveness of the masses to leadership - measured by ability to assimilate political information and participate actively and rationally in elections, the self-organisation of the cross-section of the citizenry into dynamic civil-society; pressuring the government into policy options and involve in political deliberations tailored towards good governance. The continuous interaction of the citizenry directly/indirectly or the criticalness of state-society relations permeated through democratic intermediators elicits democratic balance. When government is responsive to the citizens and provides services that are only 'public good' and aggregated by the citizens, democracy can safely be said to be at a balance. Mark (2009[28]) revealed three dimensions of democratic deficits to include, normative, empirical and functional.

Firstly, "from a normative perspective, governments are in democratic deficit when political arrangements fail the expectation that participation should elicit government responsiveness". Secondly, from an empirical perspective, governments are in democratic deficit when their citizens come to believe that they cannot use their participatory opportunities and resources to achieve responsiveness. Thirdly, "from a functional perspective, governments are in democratic deficit when they are unable to generate the legitimacy from democratic sources they need to govern".

The three dimensions of democratic deficit lead to protest participation whereby citizens resent politics. Apathetic participation will only worsen the political situation and if the different agencies of the political game allow the situation to soar for a very long time, the system might find itself sliding towards collapse and 
revolution. As long term apathy when combined with gross leadership deficit manifested in deprivation will only ripen a frustration that might will rail-road into aggression.

\section{The Essence of Critical Citizenry in Good Governance and Political Transformation}

The three dimensions of citizenship viz; as a legal status, political agents, and identity lend credence to the contractual dimension of the concept of citizenship which when harnessed in the democratic system is essential in the following ways;

\subsection{Forming government/becoming part of government}

Critical citizens plays formidable roles in forming and or determining the formation of government through the exercise of their fundamental human rights which includes the right to belong to association which may include political parties, civil-society group, etc and also the right to participate in politics as enshrined in varieties of documents including the African Charter on Human and Peoples Right (ACHPR), Universal Declaration of Human Rights and International Covenant on Civil and Political Rights (ICCPR). The UDHR [29] maintained that;

Everyone has the right to take part in the government of his country, directly or through freely chosen representatives.... The will of the people shall be the basis of the authority of government; this (will) shall be expressed in periodic and genuine elections which shall be universal and equal suffrage and shall be held by secret vote or by equivalent free voting procedures.

\subsection{Agenda setting, molding, sharpening and Probing Government}

Participation gives political leadership direction and apprises them of the views of the masses. The masses express dissent to certain government policies through intensively making their views known to government. Politics is a public act and as such participatory, and not an exclusive reserve of a cabal or mafia (Ayoade 1997: 3[30]). In the real sense, participation keeps government at home with the best decisions to take and policies to avoid in a democratic system. Probing and confronting government forms a formidable function of political citizenship. When the citizens participate actively in politics they constitute a court to those in power, probing them to avoid excesses and compelling obedience to popular will and acceptable mores.

In all when these roles are effectively carried out by the citizens, it will elicit government responsiveness and accountability, and the attainment of 'public good'.

\section{Political Participation (Critical Citizenry) in Nigeria: Character and Impediments}

The character of citizens' participation in Nigeria is an embodiment of deficits manifested in the following impediments;

\subsection{Political Culture of Poverty and concomitant Information Society Deficit}

Majority of Nigerians fall within the category of being poor with figures in this regard ranging from above $70 \%$. Poverty develops its own political culture which has implications on assimilating political information, assessing governance, voting behaviour, public opinion, political protest, etc. The poor are usually characterized as being economically challenged, emotional, uninformed, irrational, uneducated; in all vulnerable to political manipulations and deceit. More so, this class of people will never choose ballot over bread rather trade choice for bread.

Information society implies a society where rational decisions are arrived at by cogent assimilation and use of information. Majority of Nigerians are uninformed due to academic gaps (illiteracy), poverty or too superstitious/religious and primordial to acquire and use balanced information.

\subsection{Class paradigm}

In the absence of a feasible followership capital, the political elite hijack the political space and perpetuate interests that are not at par with popular participation. Godfatherism has remained the bane of Nigerian politics where the patrons impose candidates on the masses and explore every option to make sure that such candidate(s) dominates power for the interest of sponsors. Elite marginalization has impeded Nigerian political development more than any other variable.

\subsection{Religious relics}

The role of religion in fermenting political apathy can be viewed from three perspectives; first is the role of religion in the service of sin, whereby the religious organisations have relegated the role of socialization for profiteering in the form of hawking prosperity and establishment of other private ventures like tertiary institutions, media outfits, etc that would need political alliance to remain afloat, and makes 'talking truth to power' impossible. Another negative implication of religion in politics in Nigeria is the cajoling of very 
believing Nigerians that God has 'a hand' in politics, invariably Nigerian religious leaders who control millions of 'believers' has often times been approached by politicians for advancing an image marketing for them. These 'gospel marketers' also extend their service to organising a widely broadcasted programmes in the form of thanksgivings for elections that were rigged or elites that defrauded the system and 'acquired' 'legal justice' (Note: that legal justice is not social justice). Religion has become an instrument of control whereby it is easily quoted by Nigerian Muslim political leaders that "Power comes from God and He gives it to whomever He pleases (Ayoade 2010 [31]). Nigerians prefer to resign to fate than to stand for their right, they rather say 'God dey' (God exist) than to put up resistance. In fact many Nigerians believe that Nigerian political deterioration will be arrested by God. Some religious group in both the Christian and Muslim flock advance a doctrine of exclusion; either with regards to gender as advanced by the Muslims or total non-participation.

\subsection{Criminalization of the Political Society/ Inefficient Civil-Society}

The Nigerian political society typified by party politics and other intricacies targeted at seizing governance has been criminalized. The ruling People's Democratic Party (PDP) has always used its power of incumbency to arm twist other parties and dominate the political system. Worst still the opposition parties that ought to step up their game in the areas of alternative policy option, strong and dynamic ideologies, checking and probing on the ruling party for accountability has rather threaded the path of seeking a romance of sentimental ideology. Every plummeting condition in the country has been politicized as a failure of leadership by the ruling party without an effort by the opposition parties to prove an alternative policy. The 'pull him down syndrome' has played out well for politicians in Nigeria who are avowed to pull the system down when not in power. The responsibility of civic education for quality citizens' participation has been relegated.

More often than not, the Nigerian civil society has proved to be a wobbly assemblage for mundane biddings and usually employed by political interest, shuttling between wage rancor and opposition party at the same time. Most times the need for bidding for long term and holistic development is forgone to wage agitations. The civil society groups are mostly pro-active in the biddings to satisfy 'group interest' devoid of the effort at social mobilization. Other self organising groups like market associations, trade/traders' unions, artisan groups, neighborhood associations has ironically found no reason for political relevance.

\subsection{Constrained Democratic Space/Debris of Military over-stay in Politics}

Nigeria suffers from constrained and shrinking democratic space. A culture of autocracy has been absolved in the formal and informal sector of the state; from family relations, religious organisations, private firms, institutions, etc. Part of the reason for this is that the involvement and over-stay of the military in Nigerian political space created a culture of militancy and dictatorship with concomitant suppressed followership.

\section{Conclusion}

From 1999 till date is a lengthy and the most expansive democratic engagement in Nigeria. The general citizenry, political and civil society organisations must not undermine the economic upshot of a consolidated as well as persistent liberal democracy. This understanding makes the democratization project very expensive to be abandoned to minority power brokers who will offer nothing less than self-service and directionless governance. Drawing from Cyril (2007 [32]), it is apposite to query; "Will the ruling elite voluntarily loosen its tight grip on power and resources, and empower the people to take decisions that touch upon their collective wellbeing? Do possibilities exist for a broad democratic alliance to effectively organise a transformation of the existing inequitable power relations". Anybody who waits for leadership to on their own offer the best of democracy is in for a very long wait. Ayoade (2010: 54 [33]) admonished, "Nigeria can work if only Nigerians work. Apathy is equivalent to an election boycott which enables the wrong contestants to win. There is a direct relationship between citizen vigilance and governmental performance. Citizens are the compass of government which and the state loses direction when it is abandoned by the citizens".

Therefore, if the developmental benefits of the democratic practice manifested through security, jobs, education, better infrastructure, rule of law and respect for human rights that preconditions these benefits, all leading to human peace, happiness and development, etc are to be reaped, Nigerians must interest themselves in the process. Nigerians must find themselves actively represented in both civil and political societies, dialoguing, participating, probing, interrogating and confronting the system for the sake of good governance. Civic education must be critically considered in both academic institutions as well as other self-organising associations like community unions, town meetings, village councils etc, that constitute the rallying point for the production of political representatives. Democratic values must be advocated and expanded in all sectors, sections and strata of the society, knowing that the easiest way to expand democratic space and reap democratic dividends is to constrain apathy and expand the frontiers for critical citizenry. 


\section{References}

[1]. D. Beetham, Conditions for democratic consolidation, Review of African Political Economy No.60, 1994, 157-172

[2]. UNDP Report, 1999

[3]. S. B. Oluwole, Democracy and indigenous governance: the Nigerian experience, in J. O. Oguejiofor (Ed.), Philosophy, democracy and responsible governance in Africa, (New Brunswick and London: Transaction Publishers 2003). 419-430

[4]. L. O. Imade, Democratizing democracy In Nigeria: the role of civil society organizations, Retrieved from, http://www.jsdafrica.com/Jsda/spring2001/articlespdf/ARC\%20\%20DEMOCRATIZING\%20DEMOCRACY\%20IN\%20NIGERIA. pdf, on $11^{\text {th }}$ January, 2012

[5]. J. A. Schumpeter, Capitalism, socialism, and democracy. 2nd ed. (New York: Harper \& Brothers 1947)

[6]. R. Dahl, Democracy and its critics, (New Haven: Yale University Press, 1989).

[7]. I. K. R. Popper, The open society and its enemies, (London: Routledge \& Kegan Paul, 1945)

[8]. A. D. Aina, Party and electoral politics, in A. A. B. Agbaje, L. Diamond. and E. Onwudiwe, (Eds). Nigeria's struggle for democracy and good governance. (Ibadan: University Press, 2004)

[9]. O. I. Albert, Pinched, ditched or jinxed? the mantra of African solutions to African problems, An inaugural lecture delivered at the University of Ibadan, Thursday, $3{ }^{\text {rd }}$ February, 2011.

[10]. W. Soyinka, Nigeria: the mistake of 1914, Tempo, Lagos, April 12, 2000

[11]. J. A. A. Ayoade, Nigeria: positive pessimism and negative optimism, A Valedictory lecture delivered to the Faculty of the Social Sciences on September 17, 2010, University of Ibadan, Nigeria

[12]. J. A. A. Ayoade,

[13]. J. 'Bayo Adekanye, The retired military as emergent power factor in Nigeria, (Ibadan: Heinemann Educational Books, 1999)

[14]. C. I. Obi, Democratising Nigerian politics: transcending the shadows of militarism, Review of African Political Economy, Vol. 34, No. 112, 2007 , 379-384

[15]. B. Okunade, Leadership: the big challenge, An Inaugural lecture, Delivered at the University of Ibadan, Nigeria, 2008.

[16]. B. Okunade

[17]. B. Okunade

[18]. A. D, Aina, Party politics in Nigeria under Obasanjo administration, Monograph Series 1, 2002,Department of Political Science and Sociology, Babcock University.

[19]. J. A. A. Ayoade, Nigeria: positive pessimism and negative optimism,

[20]. The Economist, February 27 - March 5, 2010.

[21]. O. B. C. Nwolise, Leadership and development in a democracy: The Obasanjo and post-Obasanjo Nigeria in perspective, text of a Public Lecture delivered to mark Nigeria's (2006) $46^{\text {th }}$ Independence Anniversary, organized by the Multi-choice Group, Abuja at the Conference Centre, University of Ibadan, on Wednesday $27^{\text {th }}$ September 2006.

[22]. R. Dahl, A preface to democratic theory, (Chicago: University of Chicago Press, 1956).

[23]. J. A. A. Ayoade, Nigeria and Squandering of hope, An inaugural lecture delivered at the University of Ibadan, 1997

[24]. I. S. Ogundiya, Democracy and good governance: Nigeria's dilemma, African Journal of Political Science and International Relations. Vol. 4(6), 2010, 201-208,

[25]. Mo Ibrahim Foundation, Mo Ibrahim Index of African Governance, Summary Published October 2011

[26]. I. O. Mbachu, Democratization and the Economy, Africa: Rivista trimestrale di studi e documentazione dell'Istituto italiano per l'Africae l'Oriente, Anno 46, No. 1, MARZO, 1991, 40-53

[27]. O. B. C. Nwolise, Leadership and development in a democracy: The Obasanjo and post-Obasanjo Nigeria in perspective

[28]. W. E. Mark, Citizen participation and democratic deficits: consideration from the perspective of democratic theory, in J. Debardelen and J. Pammett (eds), Activating Citizen, (New York: Palgrave MacMillan, 2009)

[29]. United Nations Declaration of Human Rights (UNDHR).

[30]. J. A. A. Ayoade, Nigeria and Squandering of hope, An inaugural lecture delivered at the University of Ibadan, 1997.

[31]. J. A. A. Ayoade, Nigeria: positive pessimism and negative optimism,

[32]. C. I. Obi, Democratising Nigerian politics: transcending the shadows of militarism

[33]. J. A. A. Ayoade, Nigeria: positive pessimism and negative optimism 